\title{
Paradigmas en progressie in die teologie: 'n Perspektief op die RGN-kongres van April 1988
}

\author{
PJ van der Merwe \\ Universiteit van Pretoria
}

\begin{abstract}
Paradigms and progress in theology: A perspective on the HRSC conference of April 1988
\end{abstract}

The title refers to a conference believed to be the first interdisciplinary meeting on said theme in South Africa held under the auspices of the South African Human Sciences Research Council in Pretoria last year. Future developments in this field may prove it a major happening in South African theology and methodology yet. An anthology of selected papers read appeared from the press recently. This article contains a number of abstracts made from the book and brief discussions of papers thus abstracted. A basic hesitancy pertaining to the meaning and encompass of the concept 'paradigm' as well as a widespread uncertainty regarding theology's accountability towards science are noted. Fears of dimensional reduction are expressed.

\section{INLEIDING}

Die boek van Thomas Kuhn, Structures of scientific revolutions, wat in 1970 verskyn het, het 'n groot impak op beide die natuur- en geesteswetenskaplike wêreld gehad. Selfs die teologie kon die invloed daarvan nie ontsnap nie. Deesdae is dit natuurlik mode om alles wat lyk na 'n belangrike metodologiese ontwikkeling 'n paradigmaverandering of selfs 'n paradigmaverskuiwing te noem. So word Kuhn se term 'paradigma' al gaande deur inflasie afgerem. Die metodologie as besinningsterrein word egter al belangriker.

Gedurende die tweede week van April 1988 het teoloë van dwarsoor SuidAfrika by die nuwe gebou van die Raad vir Geesteswetenskaplike Navorsing in Pretoria byeen gekom vir 'n kongres van amper drie dae met die tema Paradigmas 
en progressie in die teologie. Sopas het 'n bundel verskyn waarin 'n seleksie van die referate opgeneem is. Die bibliografiese besonderhede is die volgende:

Mouton, J, AG van Aarde en WS Vorster (ed) 1988. Paradigms and progress in theology. HSRC Studies in Research Methodology 6. Pretoria: RGN.

Hierdie artikel wil die publikasie van naderby bekyk en ook van die geleentheid gebruik maak om die een en ander oor die kongres self te sê.

\section{OPMERKINGS OOR DIE KONGRES}

\subsection{Algemene waardering}

Die kongres kan nie anders as betekenisvol bestempel word nie. Die tema is lank reeds in die teologie aan die orde, maar hierdie is waarskynlik die eerste noemenswaardige kongres in Suid-Afrika wat uitsluitlik daaroor gehandel het. Die organiseerders was stellig verras oor die wye reaksie wat hulle uitnodiging ontlok het. Daar was elke dag goeie bywoning en kongresgangers het dit allerweë as 'n leersame ervaring bestempel.

Die voordragte was oor die algemeen van 'n hoë standaard en die besprekings was meestal interessant en dikwels intensief. Hoewel die meeste voordragte 'n sistematiese strekking gehad het, het die Sistematiese Teologie nie noodwendig die toneel oorheers nie. Die meeste teologiese dissiplines was op een of ander wyse verteenwoordig, asook Filosofie.

\subsection{Tog ook frustrasie}

Die kongres het helaas ook bepaalde frustrasies opgelewer waarna ons kortliks kyk.

Die vernaamste frustrasie was waarskynlik dat die kongres oorvol van voordragte en inligting was. Die meeste voordragte was gewigtig en alles behalwe maklik om te volg, veral in die afwesigheid van vooraf-gesirkuleerde tekste. Daar was waarskynlik genoeg geleentheid vir diskussie en meningswisseling, maar die entoesiasme daarvoor het merkbaar afgeneem namate die vermoeienisfaktor sy $10 l$ begin eis het.

Die kongres kon dus meer doelmatig gestruktureer gewees het. As in aanmerking geneem word watter hulpbronne die RGN tot sy beskikking behoort te hè 
met betrekking tot die teorie en tegnologie van kongres-optimalisering, is so 'n verwagting nie onbillik nie.

Dit moet darem genoem word dat enkele referente regtig moeite gedoen het om hulle voordragte met doelmatige visuele materiaal te illustreer, terwyl 'n paar selfs op eie inisiatief afskrifte van hulle voordragte versprei het.

Dit het vroeg duidelik geword dat daar uiteenlopende opvattings omtrent die begrip 'paradigma' bestaan. Nie alleen is dit opgeneem om op verskillende vlakke van abstraksie te funksioneer nie, maar selfs die inhoud van die begrip is uiteenlopend verstaan. Soos begryp kan word, was so 'n fundamentele spraakverwarring nie bevorderlik vir sinvolle debatvoering nie. As egter in aanmerking geneem word dat dit die eerste keer was dat die tema op so 'n verteenwoordigende skaal aangepak is, is dit noodwendig dat die kongres 'n eksperimentele kleur moes hê. Die blote feit dat die kongres plaasgevind het, moet as 'n wins beskou word.

Die organiseerders kan natuurlik heelwat vergewe word op grond van hierdie keurig versorgde bundel wat die kongresganger die geleentheid bied om dit wat hy gehoor het teen sy eie pas te herkou.

\section{DIE BUNDEL}

Dit is interessant dat die bundel 'n ander indeling volg as die kongres en dat sommige voordragte wat gelewer is, nie opgeneem is nie.

Die indeling is soos volg:

'n Inleidende voordrag deur P Hefner.

Deel 1: Paradigmas in die teologie. Voordragte deur WS Vorster, AG van Aarde en B Lategan.

Deel 2: Teologie en rasionaliteit. JWV van Huyssteen, DJ Smit, GC Velthuysen, PJ Hartin en PJ Naudé.

Deel 3: Fundamentalisme. JN Vorster, J Mouton \& JC Pauw en E Echeverria.

Deel 4: Godsdienstige ervaring. JS Krüger, JG de J van Arkel, F Edwards, J Moulder en M Prozesky.

Deel 5: Teologiese taal en objektiwiteit. JS Stoffberg, W van der Merwe en JG du Plessis.

Deel 6: Teologiebeoefening in hedendaagse Suid-Afrika. J Mossala, S Maimela en F Deist.

Deel 7: Algemeen. P Coertzen, J Cook, WR Domeris, JH Petzer en J Rousseau. 
Die onderhawige artikel verteenwoordig 'n bepaalde ervaring van en perspektief op die kongres, en 'n eie poging om tot verstaan van die basiese tema te kom. Uit die aard van die saak is dit onmoontlik om elke voordrag te bespreek en slegs 'n seleksie van voordragte word van naderby bekyk.

Om andere se denkvrugte te interpreteer en saam te vat, hou 'n sekere risiko in. Lesers word by voorbaat gewaarsku om wat so gewaag is, aan die bundel self te kontroleer. Referente word by voorbaat om verskoning gevra.

\section{ENKELE VOORVRAE}

\subsection{Fundamentele oorwegings wat dalk meer aandag kon gekry het}

Een van die vernaamste probleme was stellig hoe ver die metodologiese vraagstelling teruggevoer moes word. 'n Maklike antwoord sou wees: na die begrip paradigma, waar 'n mens dit ook al wil naspeur. Dit is duidelik dat baie referente dit so verstaan het, maar behalwe dat paradigma self 'n moeilik grypbare begrip geblyk te wees het, was dit 'n vraag of die tema so verskraal kon word?

Verskeie sprekers het daarop gewys dat die huidige metodologiese debat in die teologie verband hou met belangrike ontwikkelinge wat die afgelope klompie dekades op kenteoretiese en wetenskapsfilosofiese gebied plaasgevind het. Derhalwe het sommiges gesuggereer of gesê dat dit eers nodig is om te vra waarom dit vir teologie nodig is om hom so diepgaande en indringend te vergewis van en te verantwoord teenoor ontwikkelinge op hierdie terreine wat buite sy gebied lê (so Smit 101 vv en Naudé $143 \mathrm{wv}$ ).

Verskeie sprekers het op die verskynsel gewys dat metodologiese verskuiwings in teologie konstant in verband gebring kan word met die werklikheidsbeeld en -benadering wat in die kontemporêre sekulêre geleerdheid of wetenskap gangbaar was (bv Vorster 32).

JS Krüger herinner ons dan dat beide teologie en wetenskap as Westerse goedere geïdentifiseer kan word. Hy suggereer dat 'n groot deel van die antwoord op die vraag wat die verhouding tussen Westerse teologie en Westerse wetenskap is en hoekom dit nodig is om metodologiese vordering in die teologie met die in die wetenskap in verband te bring, gevind sou word in 'n simbiotiese verhouding tussen teologie en geleerdheid (214). Beide wetenskap en teologie is deel van die groter patroon van 'kondisionaliteit' in die benadering en ervaring van die werklikheid. Hy wys dan ook op die diepgaande metodologiese implikasies hiervan vir die universele pretensie van beide wetenskap en teologie. 
Op grond van die sneluitbreidende invloed van Westerse tegnologie en natuurwetenskap word dikwels aanvaar dat Westerse wetenskap per se universele geldigheid en aanspraak het. PJ Naudé herinner ons daaraan dat daar baie wêrelddele is waar die produkte van hierdie tegnologie en wetenskap aangewend word, sonder dat die tradisionele geesteskultuur op dieselfde wyse deur Westerse wetenskap en mentaliteit binnegedring is ( $143 \mathrm{w}$ ).

Tog kry 'n mens dikwels die indruk dat wetenskap in die kongres meestal as universeel aanvaar is, omdat dit met sogenaamde universele beginsels, uitgangspunte of waardes werk. Daar is egter selde oorweeg of dit nie bloot 'n geval is dat die wetenskap homself universeel verklaar nie.

Krüger suggereer dat die Westerse teologie (en sy metodes) derglike parogialismes vertoon en dat hy sy universele roeping en verantwoordelikheid nie ernstig kan opneem solank hy die gegewenheid van verskillende godsdienste (wat onder andere as reusagtige, alternatiewe sisteme van werklikheidsverstaan funksioneer) en kulture, asook sy eie gekondisioneerdheid en kondisionaliteit, miskyk of nie bereid is om dit in sy benadering te verdiskonteer nie.

Naudé suggereer dat Christene in die Derde Wêreld graag wil glo dat die evangelie ' $n$ boodskap vir alle mense is, maar as dit aan hulle uitgespel word deur en in terme van 'n teologie wat duidelik in samehang met Westerse geleerdheid ontwikkel het en verkeer, kan hulle nie anders as om oor die gesag daarvan te begin wonder nie $(143 \mathrm{vv})$, veral as genoemde geleerdheid in hulle oë 'n godlose en mensonvriendelike geleerdheid is (- PJvdM). Die bestaansreg van 'n teoretiese teologie wat nouer aansluiting soek by die akademiese wèreld as by die behoeftes van die kerk en die mense (natuurlik soos hulle dit beleef), vind hulle moeilik om te begryp. Daar is ook baie Westerse gelowiges wat dit 'n rare opset vind (Smit 102).

Uiteraard bestaan die gevaar altyd dat ' $n$ mens so in voorvrae kan vasval dat die eintlike vrae nie aan die beurt kom nie. Daarom is dit soms geregverdig om met die deur in die huis te val. Dan sou dit nogtans verwag kon word dat daar heeltyd met 'n bewussyn van die relevante voorvrae gewerk word.

\subsection{Teologie in die kring en teologie van buite die kring}

Ek kon nie agterkom dat die 'insider-outsider'-beginsel in hierdie kongres 'n beduidende rol gespeel het nie. So onbeduidend as wat dit mag lyk, is dit 'n belangrike metodologiese voorvraag. Dit bepaal die hoek en inslag waarmee gewerk en geëvalueer word.

Om teologie as 'insider', dit wil sê as gelowige teoloog, namens en in solidariteit met 'n bepaalde geloofsgemeenskap en -tradisie, te beoefen, gaan 'n 
ander resultaat tot gevolg hê en verwag om anders gelees te word as wanneer 'n 'outsider's stance' ingeneem word. Dit veronderstel 'n simpatieke, saamdinkende en saambelydende gehoor. Hierdie soort teologie kan kerklike teologie genoem word. In sommige kritiese kringe word daarop neergesien as 'n obskurantisme, maar dit is nie altyd billik nie. Dit kan oop en teoreties goed beredeneerd wees. Dit kan selfs in gesprek tree met menings buite die kring. Die styl bly nogtans meer 'retories' as wat die geval sou gewees het as 'n gedistansieerde teoloog aan die woord was.

Gedistansieerde teologie is nie noodwendig klipchristenteologie nie, maar kan die resultaat wees van ' $n$ bepaalde dissipline wat die teoloog homself as akademikus oplè. Betrokke by sy eie teologiese denke handhaaf hy nogtans 'n sekere (onpartydige) distansie daarteenoor. So 'n oefening kan akademiese of teoretiese teologie genoem word. Hoewel die taal onvermydelik metafories is, probeer dit retoriese meerduidigheid minimaliseer.

Die stelling kan gemaak word dat baie teologiese werke in die verlede onregverdig gekritiseer is, gewoon omdat die kritikus dit vir homself nie uitgemaak het of die betrokke werke veronderstel is om binne die kring of daarbuite gelees te word nie. So kan Barth se Godsleer, as teoretiese teologie geëvalueer, maklik afgeskiet word as 'n projektionisme, maar, as kerklike teologie gelees, beleef word as innige geloofsdenke, -taal en -getuienis oor God. Op dieselfde wyse sou die voordrag van GC Velthuysen in hierdie bundel deur kerklike lesers moontlik as bevreemdend ervaar word, terwyl dit in die eerste plek nie in 'n kerklike styl of vir kerklike lesers geskryf is nie, maar met die oog op 'n teoreties teologiese gesprek.

Ek wil dus waag om te sê dat hierdie metodologiese beginsel dit vir die teoloog moontlik maak om tegelyk aan twee, oënskynlik teenstrydige, metodologiese teorieë vas te hou. Om die onderhawige bundel as voorbeeld te neem: 'n Teologie wat vanuit, in solidariteit en namens die kring van gelowiges bedryf word en op dieselfde kring as luisteraars of lesers gemik is, kan Platinga se regverdiging vir persoonlike geloof navolg. Dieselfde teoloog kan egter 'n krities realistiese benaderingswyse volg wanneer hy teoretiese teologie bedryf wat daarop gemik is om met die groter korpus van wetenskaplikheid te skakel. Dat dit nie skisofrenies is nie, maar in ooreenstemming met die nuwe opvattings van wetenskaplikheid, word uit hierdie bundel duidelik.

\section{OORSIGBESPREKING VAN 'N SELEKSIE VAN VOORDRAGTE}

Die voordragte word aangebied in 'n volgorde wat funksioneel is vir die hoek waarmee gekyk word. 
Die uitdaging van 'n nuwe fisika

Die baie goeie voordrag van JG de $J$ van Arkel, Theology beyond Newton: a quantum leap (223-238), bied ' $n$ interessante en nuttige oorsig van konsepsuele ontwikkelings op die gebied van die fisika gedurende die twintigste eeu en die implikasies daarvan vir die teologie. Hy toon aan dat baie van die metodologiese begrippe wat gedurende die kongres hanteer is, na die empiriese vakke, veral die fisika, teruggevoer kan word.

Van Arkel begin sy voordrag deur na 'n stelling van Peacocke te verwys: God, mens en natuur vorm 'n klassieke trio in filosofiese en teologiese nadenke. Die implikasie is dat enige diepgaande verandering in die wyse waarop oor enige van hierdie drie onderwerpe gedink word, die denke oor die ander moet affekteer. Teologiese denke is tot nou bepalend beïnvloed deur die kenteoretiese en wetenskaplike paradigma wat deur groot fisici soos Copernicus, Kepler, Galilei, Newton en filosowe soos Descartes en Kant gevestig is en wat as 'meganisties' getipeer kan word. Vanaf die begin van hierdie eeu het daar egter op die gebied van die mikrofisika ontwikkelings gekom wat tot 'n nuwe paradigma gelei het. Hedendaagse teologiese denke word daardeur onder spanning geplaas.

Met die ontdekking van kerne, atome, molekules en dies meer en die ontwikkeling van 'n mikro-fisika het die Newton-wette in die agtergrond geskuif. Daarmee saam het ook die sekuriteit wat dit gebring het, naamlik dat daar onder die oënskynlike chaos altyd 'n ordelike en konsekwente netwerk van wette en beginsels funksioneer, verkrummel.

Max Planck stel dat die fisiese werklikheid as 'n samehang van kwanta gesien moet word. Mikro-fisika verwys byvoorbeeld na 'n ander kwantum as die van gewone fisika. 'n Kwantum mak sy eie verwysingsraamwerk uit wanneer daar gekwatifiseer word en funksioneer volgens sy eie wette.

Die oorgange tussen kwanta is spronge. Die fisiese werklikheid, soos gesien deur die bril van die teorie, is nie homogeen nie, maar heterogeen.

Die implikasies van die kwantum-teorie het geleidelik ook na die biologie, antropologie en ander dissiplines uitgebrei. Wat as teorieë begin het, het 'n nuwe paradigma geword.

Van Arkel identifiseer dan 'n aantal begrippe na aanleiding van die nuwe fisika wat hy 'meta-begrippe' noem en wat hy meen in die rigting van 'n nuwe algemene paradigma in die wetenskap dui.

- 'n Nuwe logika en nuwe wette

Daar is nie so iets as ' $n$ absolute logika nie. Einstein ontdek dat ons vry is om met totaal nuwe, selfs oënskynlik onlogiese, idees en paradigmas te eksperimenteer. Sy 
eksotiese idees lei hom tot die relatiwiteitsteorie.

\section{- Interaksie tussen subjek en objek}

Die kwantum-epistemologie erken dat elke poging om die werklikheid waar te neem of te meet, met die werklikheid peuter en dat daar dus geen 'objektiewe' waarneming of meting moontlik is nie. Ons sien net dit waarvoor ons teorie ons toerus om te sien. Ons sien nooit hoe atome self lyk nie, maar bloot hoe hulle reageer as ons hulle aan ons waarnemingsprosedures onderwerp. So besef die kwantum-epistemologie dat ons in der waarheid slegs van interaksies (dws, tussen subjek en objek) kennis versamel.

\section{- Komplementariteit}

Volgens die kwantum-epistemologie kan 'n ding gevolglik twee dinge tegelyk wees, indien dit aan twee waarnemingsprosedures tegelyk onderwerp word. Die kwantum. veld-teorie gaan selfs verder en voeg twee oënskynlik teenstrydige begrippe saam in een teorie. So is die Kantse kategoriese imperatief omvergewerp. Paradoks word aanvaarbaar, omdat dit die gevolg kan wees van die mentale strukture wat ons gebruik om tot verstaan en verklaring te kom.

\section{- Non-dualiteit}

Tradisionele onderskeidings soos 'organies' en 'anorganies' loop deurmekaar omdat die definisies waarop dit berus, hulle bodem kwytgeraak het. Begrippe soos 'bewussyn', 'denke' en 'liggaamlikheid' moet opnuut gedefinieer word en ou dualismes verloor hulle betekenis.

\section{- Heelheid}

Sommige geleerdes het van die kwantum-meganika afgelei dat alles in ons heelal deel is van 'n geheelomvattende, 'organiese' patroon, 'n geheel sonder soom of naat. Die fisiese wêreld is ' $n$ netwerk van relasies tussen elemente waarvan die betekenis afhang van hulle verhouding tot die geheel. As ons oënskynlike afsonderlike entiteite teenkom, is dit niks anders as 'n beeld wat ons waarneming 'gevries' het nie. So 'n beeld kan verder selfs niks anders wees as 'n korrelasie wat ons getref het nie.

Dit is verder van betekenis dat plek amper irrelevant is in hierdie relasies. Op subatomiese vlak veral is interrelasies en interaksies van die geheel meer fundamenteel as die 'onderdele' self. 
- Waarskynlikheid

Determinisme moes gevolglik plek maak vir waarskynlikheid. Voorspelbaarheid en sekerheid verval. Slegs waarskynlikhede kan voorspel word.

- Tydsrelatiwiteit

Tyd word dinamies. Dit kan rek of krimp, buig of selfs stop. Dit kan egter nie terugloop nie. Energie, tyd en ruimte word kante van dieselfde saak.

'n 'Nuwe fisiese werklikheid' en 'n nuwe paradigma

Van Arkel skets enkele trekke van 'n nuwe paradigma na aanleiding van voorafgaande en hy gebruik insigte uit sisteemteorie, kibernetiek en inligtingsteorie daarvoor. Hy verwys na Torrance as hy sê dat die moontlikheid bestaan dat die nuwe fisika vriendeliker teenoor die Christelike geloof sal wees as die dualistiese een wat tans grotendeels nog gangbaar is (228) (vgl egter opmerking hieronder oor holisme).

\section{- Konstruktiwisties}

Van primêre betekenis is dat 'n nie-objektiwistiese en nie-positiwistiese houding deur die teoloog ingeneem sal word. Die teoloog en dit wat hy bestudeer, maak 'n interafhanklike en onderling-bepalende paar uit. In die kibernetiek is dit 'n bekende beginsel: die kibernetiek wat ontwerp word om die waarneming van sisteme te reël, moet noodwendig vergesel word van 'n kibernetiek wat ontwerp word om die sisteme van waarneming te reël.

Van Arkel kies vir 'n kibernetiese konstruktiwistiese paradigma van ken en verstaan. Bateson sê dat ons eie verstand die beelde uitdink wat ons meen ons waarneem. Ons ken slegs deur telkens opnuut vir ons 'n model van dit wat ons wil ken, te konstrueer. Ons is voortdurend besig om vir ons nuwe ken-strategieë uit te werk. Dit is dinamies. Dit ontken nie dat daar 'n objektief is nie, maar verkeer heeltyd in 'n wisselwerking daarmee.

- Sistemies

Kennis en denke word deel van 'n groter dinamiese geskakeldheid en interafhanklikheid. Die kennispoging besef dat hy van buite af daarop inkom (terwyl die ou meganistiese benadering gemeen het dat daar van binne na buite gewerk word). Dit rig hom op die funksionele en teleologiese samehang van dinge.

Bateson sê dat ons voorheen vir ons abstrakte 'eienskappe' van relasies en die ervaring van interaksies afgelei het en dit tot statiese 'dinge' gesubstansieer het. 
Dit hou ook verband met die verskynsel van reïfikasie: 'n Bepaalde gedragspatroon kry 'n naam en dan word die naam agterna gebruik om die gedragspatroon mee te beskryf en te verklaar. Ons moet nou leer om na dinamiese patrone van relasies en interaksies op te let en kennis in terme daarvan te interpreteer.

\section{* Holisties}

Daar bestaan nou minder gronde as ooit tevore vir 'n gefragmenteerde mensbeskouing en egosentrisme. Evangelie en geloof raak die hele mens en versoen die mens met God, met sy naaste, met die skepping en homself. Dit beteken egter nie gelykskakeling nie. (PJvdM: Dit is bekend dat enkele kosmoloë hulle in kosmologiese teoriebou tot Indiese kosmogoniese mites gewend het, omdat hulle die Christelike skeppingsteologie dissonant met die 'organismiese' kosmologie vind)".

\section{- Dinamies}

Dit gaan dus om 'n sisteem wat oop is, wat in voortdurende dinamiese 'lewende' wisselwerking met sy konteks en dit waarop hy hom rig, verkeer. Dit bou nie alleen homself op nie, maar dien ook dit waarop hy gerig is. Die ou staties-analitiese benadering het alles waarop dit gerig is, 'doodgemaak', gevries.

\section{- Ekwifinaal (=doelgerig ongeag wisselende omstandighede)}

'n Sisteem wat in terme van sy eie innerlike doel en roeping funksioneer, sal sy einddoel bereik, selfs onder wisselende omstandighede. Dit is organies, dit leef.

Op dieselfde wyse funksioneer teologie onder wisselende omstandighede en in baie vorme om op die ou end by dieselfde een doel uit te kom. Omdat teologie nie afsonderlik van die geloof funksioneer nie, is dit deel van die lewende geheel van die geloofsgemeenskap wat op sy beurt sy eenheid en einddoel in God, sy Seun en sy Gees vind.

\section{- Kiberneties}

Kibernetiek bestudeer patrone en organisasie, nie stof en voorwerp nie. Dit neig tot 'n holistiese benadering, nie atomisme nie.

Dit mag wel nog nuttig wees om te analiseer en te dissekteer, op voorwaarde dat ons nie die samehange vergeet wat ons kunsmatig tussen hakies geplaas het nie.

Daar is diegene wat probeer om die patrone self te isoleer en te reifeer, maar dit kan slegs relatiewe en waarskynlikheidswaarde hê. Teologie moet kiberneties word.

- Vgl ook AG van Aarde se kritiek teen die organismiese holisme 
- Sirkelagtig

Ons is so beset met die Newtonse opvatting van lineëre kousaliteit dat ons onbewustelik ons ganse geloofsleer op 'n reglynige model gebaseer het. As gevolg daarvan beleef ons die heilsgebeurtenisse as dinge wat of baie lank gelede plaasgevind het of baie ver vorentoe moet plaasvind. Die primitiewe mens met sy sikliese tydbegrip ervaar die evangelie as iets wat amper kontemporêr is.

Gesien die holistiese opvatting van tyd en werklikheid, kan ons goedskiks oorskakel na 'n opvatting van tyd en kousaliteit wat meer sirkelagtig is en die heilsgebeure dus nader aan ons bring.

Die kritiese rasionalisme en die teologie

PJ Hartin se voordrag, Theology and critical rationalism: how theology faces the challenges of an new paradigm (129-141), gee 'n nuttige historiese en deskriptiewe oorsig van sekere metodologiese ontwikkelings in wetenskapsfilosofie en teologie.

Hy identifiseer die opkoms van die kritiese rasionalisme van Karl Popper as een van die belangrikste wetenskapsfilosofiese ontwikkelinge versover dit die metodologie van die wetenskap aanbetref. Popper het teen die Weense Kring met sy positiwistiese (en naïewe) opvatting van rasionaliteit en empirie reageer. Hy dui teorie- en hipotesevorming as die sentrale aktiwiteit in die wetenskap aan en vervang die beginsel van verifikasie met falsifikasie. Die kritiese rasionaliteit ontwikkel hierna vinnig as ' $n$ eie metodologiese rigting, tot so 'n mate dat van 'n paradigma-omwenteling sprake is.

Dit het ook in die teologie sy weerklank gehad, in die denke van manne soos Schillebeeckx en Pannenberg.

Die volgende metodologiese beginsels in hulle teologie dui vir hom op paradigmavernuwing:

- Teologie begin met en veronderstel gesag. Dit moet egter nie as outoritêre gesag opgeneem word wat kritiese denke veto nie. Teologiese gesag dui hoogstens die pad aan waarlangs teologiese kennis oor eeue heen gevorder het. Finale gesag is in God gesetel wat sin aan alles gee. Dit is nie 'n outoritêre, wettiese gesag nie.

* Teologie se werk is om hipoteses te formuleer om die nuwe vraagstellinge wat die tyd voortbring, tegemoet te kom. Finale kennis is nie voor die eschaton moontlik nie. Teologie se kennis is daarom nooit meer as hipoteties nie. 
* Teologie moet erkenning verleen aan redelikheid en kritiek as basiese wetenskaplike beginsels wat ook vir die teologie geld. Die hipotetiese kennis van teologie bly altyd toetsbaar en falsifieerbaar.

- Die aanvaarding van sekere kriteria aan die hand waarvan toetsing van teologiese uitsprake/hipoteses plaasvind. Dit is die volgende:

- Saaklike en logiese koherensie.

- Waarskynlikheid en doelmatigheid van elke onderdeel van die hipotese.

- Eenvoud en helderheid.

- Vermoë om die Christelike geloof te verklaar.

- Vermoë om die totale werklikheid te verklaar.

- Inagname van verwante kennisterreine.

- Voorlopigheid en die vermyding van outoritarisme.

* Terugkeer na die oorspronklike probleemstelling om te kontroleer of die nuwe hipotese inderdaad daarin slaag om die vraagstelling beter te hanteer as bestaande hipoteses.

$P$ Hefner (Lutheran School of Theology, Chicago), Theology's truth and scientific formulation (11-28), gaan uit van die krities-rasionalistiese metodologie van $K$ Popper en navolgers. Die voordrag is 'n poging om te illustreer hoe die insigte van hierdie metodologie in die teologie aangewend kan word om ' $n$ wetenskaplike teorie te formuleer en 'n lewensvatbare navorsingsprogram van stapel te stuur.

Hefner gaan van die standpunt uit dat die Christelike teologie inherent 'n universele belangstelling het en dat teologiese uitsprake 'n groter toepaslikheid soek as die geloofsgemeenskap waar dit oorspronklik geformuleer is. Daarom moet dit ook ervarings en kennis wat die betrokke gemeenskap te bowe gaan, verdiskonteer. Wanneer teologie vandag universele of algemeen humane toepaslikheid soek, is dit nodig dat dit een of ander verstandhouding met die wetenskap bereik en dat teologiese uitsprake hulleself in die gestalte aanbied van wetenskaplike teorieë. So moet hulle dan ook aan bepaalde metodologiese norme voldoen, soos gekontroleerde dataverwysing, falsifikasie en dies meer.

Met hierdie uitgangspunt bied hy 'n ontwerp aan vir teologies-wetenskaplike teoretisering en 'n gepaardgaande navorsingsprogram. Hy illustreer dit met 'n denkeksperiment.

Soos Popper sien hy die falsifikasie-eis as die vernaamste toetssteen vir ' $n$ geldige teorie en gevolglik wy hy 'n groot deel van sy ontwerp hieraan. 'n Geldige teorie moet ten minste potensieel falsifieerbaar wees. Dit skep probleme vir 
teologiese uitsprake, aangesien hulle altyd 'n werklikheidsberoep bevat wat in beginsel nie falsifieerbaar is nie, naamlik 'n beroep op God of sy openbaring.

Om hierdie probleem te bowe te kom, wend Hefner hom na die denke van Lakatos (1978) wat sê dat die teoretiese stelsel (van 'n lewensvatbare navorsingsprogram) bestaan uit 'n harde teoretiese kern, 'n omringende skild van hulphipoteses en 'n aggressiewe heuristiese meganisme." Die teoretiese kern wat volgens Hefner min of meer dieselfde saak is as Thomas Kuhn (1970) se paradigma (18), word teen falsifikasie beskerm deur hulphipoteses wat hulle, soos die ablatiewe skild van 'n terugkerende ruimtekapsule, beskikbaar stel vir falsifikasie. Die heuristiese meganisme is op sy beurt besig om anomalieë uit te snuffel en betyds nuwe hulpteorieë te ontwerp om dit te verdiskonteer.

Dit herinner nogal sterk aan wat Hick (1985:52) die Ptolemeise skema noem: 'n basiese teorie wat aangevul word met 'episikliese' hipoteses. Soos Hick toegee, word dit amper onmoontlik om so 'n teorie te falsifieer. Die Ptolemeïse sonnestelsel is nie regtig 'gefalsifieer' nie. Dit is gewoon verplaas deur die Copernicaanse stelsel wat dieselfde gegewens in terme van 'n veel eenvoudiger teorie verklaar het.

Lakatos impliseer ook (volgens Hefner) dat 'n nuwe teorie eerder 'n bestaande verdring as falsifieer deurdat die nuwe teorie 'stunning, dramatic and unexpected interpretations' moontlik maak.

Dit blyk dan dat falsifikasie nie so 'n eenvoudig saak is nie. Dit raak die krities-rasionalistiese beskouing van wetenskaplikheid tot in die wese daarvan. Verder wil dit lyk of die teorie van teorieverplasing in terme van hierdie benadering nog heelwat uitgepluis sal moet word.

Die meriete van Hefner se stuk lê waarskynlik daarin dat hy die implikasies van Lakatos se benadering vir die teologie en enige poging om 'n lewensvatbare navorsingsprogram (volgens hierdie benadering) daarin op dreef te kry, manmoedig probeer uitspel en illustreer aan die hand van eksperimentele denke. Sy oefening is eerlik en goed deursigtig.

Vrae wat aan Hefner gevra kan word, het te doen met begrippe wat hy net in die verbygang aansny. So byvoorbeeld die begrip 'navorsingsprogram'. Lakatos brei die begrip 'navorsingsprogram' uit om selfs sulke groot sake soos 'Marxisme' en 'Freudianisme' daarmee te beskryf. Sou 'n mens die Popper-Lakatos-benadering as sodanig ook 'n 'navorsingsprogram' kon noem? Watter posisie moet 'n mens dan

Van Huyssteen spreck in sy voordrag skerp kritiek uit teen Nancy Murphy se oefening in Lakatos se metodologie (87). 
inneem om so 'n oefening te kan beoordeel?'

Die vernaamste kritiek teen Hefner is dat hy dit nie buite die skaduwee van die genoemde benadering waag nie en dus benadering-immanent dink.

Kritiese realisme in die teologie

Kritiese realisme, wat na Kant teruggevoer kan word, erken die subjektiewe aard van waarneming en ervaring, maar weier om te aanvaar dat die mens geen toegang tot die werklikheid het nie. Menslike waarneming en ervaring slaan neer in allerlei uitdrukkingswyses. Via kritiese hantering en interpretasie van sulke uitdrukkings kan die wetenskaplike 'n konsepsuele beeld van die werklikheid konstrueer.

JWV van Huyssteen bied sy eie 'weak form of critical realism' aan as 'n nuwe metodologiese benadering in die teologie. Hierdie benadering gaan onder andere terug na Pannenberg se skema.

Vanweë sy boek, Teologie as kritiese geloofsverantwoording (1986), het Van Huyssteen se naam gedurende die kongres herhaaldelik opgeduik. In 'n sekere sin maak sy voordrag, Paradigms and progress: inference to the best explanation (81-90), een van die wentelpunte in hierdie bundel uit.

Sy standpunt is dat teologie onlosmaaklik met rasionaliteit te doen het versover die teologie met waarheidsaansprake van kognitiewe pretensie werk of self sulke aansprake maak. Hierdie aansprake wil ook verklaar of verduidelik.

Rasionaliteit, verklaring en waarheid staan uiteraard ook in wetenskap self sentraal. Van Huyssteen sien rasionaliteit as die trefwoord in hierdie samehang.

Die wetenskapsfilosofiese ontwikkeling na Kuhn aanvaar geen skerp onderskeid meer tussen verskillende vorme van rasionaliteit nie. Wetenskaplike rasionaliteit word gesien as 'n toespitsing van normale, alledaagse redelikheid. Die rasionaliteit wat in teologie leef, gaan ook op gewone redelikheid terug. Teologie en wetenskap moet dus 'n kenteoretiese konsonansie vertoon.

Van Huyssteen sien sy 'qualified and weak form of critical realism as an adequate epistemological model of rationality for theology'. Dit gaan primêr om die verklaringsvermoë van teologiese uitsprake, maar nie op dieselfde manier waarop in die natuurwetenskappe verklaar word nie. Die werklikheid waarna hierdie 'realism' verwys, is in die laaste instansie God, maar slegs via die werklikheid en neerslag van godsdienstige ervaring en metaforiese verwysings.

\footnotetext{
- $\quad$ 'n Bewys dat die begrip 'navorsingsprogram' onduidelik is: Hefner stel die 'harde kern' gelyk aan Kuhn se paradigma (18), Ierwyl PJ Naude die navorsingsprogram as sodanig daarmec gelyk stel (146). Dit dui natuurlik ook daarop dat Kuhn se begrip 'paradigma' onduidelik is.
} 
And what is offered is no strong form of defence for theism but an attempt to argue how and why theological statements can claim tentatively to refer to God at all.

Those metaforic and interpreted expressions around which the language of the Christian religion cluster, can in this sense be said to have justified themselves as meaningful and referential to vast numbers of people throughout the centuries and across cultures. It is this kind of experiential adequacy, and not a justified certainty, which makes a belief a responsible belief. And a model of rationality which can accommodate this, is already justifying its claim to epistemological adequacy (83).

Hy sê verder dat teoloë te maklik aanvaar dat metafore nie-kognitief is.

The most interesting metaphors in both theology and science are those which suggest an explanatory network and are vital at the 'growing edges' of our reflection".

Teologiese teoretisering wat daarop gemik is om godsdienstige ervaring en teologiese refleksie te verhelder, kan dus daarop aanspraak maak dat dit 'n geldige verklaring- en verduidelikingspoging op hierdie terrein verteenwoordig.

Een van die kritieke teen Kuhn is dat sy skema nie in staat is om teoretiese meningsverskil te hanteer of te verduidelik waarom wetenskap ten spyte van 'n pluraliteit van teorieë en paradigmata vooruitgaan nie. Hier lyk dit of 'n swak vorm van kritiese realisme die uitkoms bied, as dit leer dat dit inderdaad moontlik is dat meer as een teorie formeel geldig kan wees en dat 'inference to the best explanation' (afleiding met betrekking tot die bes moontlike verklaring/verduideliking) as metodologiese beginsel erken moet word. So iets lewer uiteindelik 'n tentatiewe resultaat, maar'n pragmatiese houding word ingeneem deur sukses as aanduiding van verklaringsgeldigheid te aanvaar.

Van Huyssteen noem die volgende aspekte as kontrolepunte vir kenmatige

W van der Merwe volg Van Huyssteen se suggestie met betrekking tot metafore en 'n metaforiese teologie op in sy voordrag From theological metaphorics to methaphorical theolony (281-294). 


\section{geldigheid:}

- Die manier waarop werklikheid verbeeld word in teologiese uitsprake, beide in 'n ontologiese en kontekstuele betekenis.

- Die vermoë om probleme krities te identifiseer en op te los, synde in hierdie geval probleme van konsepsuele en ervaringsaard.

* Die konstruktiewe en progressiewe aard van teologiese teoretisering".

Uiteindelik kom dit daarop neer dat die voorlopige of benaderde geldigheid van 'n teorie gemeet word aan sy sukses en vordering met verklaring of verduideliking. Hierdie vordering is self ' $n$ vorm van afleiding met betrekking tot die bes moontlike verklaring. Kritiese realisme erken dus die konjektuuragtigheid van alle teorieë. Van die waarneming dat 'n teorie die bes moontlike verklaring bied, kan die afleiding gemaak word dat die waarskynlikheid daarvan ook hoog is. Daar word egter geen pertinente of direkte waarheidsaanspraak gemaak nie, omdat dit waarna ons metaforiese uitsprake verwys, nie direk aan ons bekend is nie. Rasionaliteit in teologie kom dus neer op die aanvaarding van daardie verklaringsmodelle wat die beste probleemoplossers is. Sulke verklaringsmodelle se funksie in teologiese teoretisering is ook primêr kognitief en alle affektiewe, hermeneutiese en kontekstuele aansprake vloei daaruit voort. (PJvdM: Dit wil voorkom of ons hier met 'n taamlike kritieke aspek te doen het).

Die krities-realistiese benadering maak dit vir ons moontlik om dit wat algemeen as waar aanvaar word in die Christelike geloof op 'n wetenskaplike, niefundamentalistiese wyse te hanteer."

Kritiese realisme kan die bestaan van God of die geldigheid van openbaringsaansprake nie bewys nie, maar kan aantoon waarom uitsprake oor God epistemologies geloofwaardig kan wees.

'Vordering met verklaring' beteken dat die ontwikkelingsaspek en historiese dimensie van teologiese rasionaliteit ernstig opgeneem word, terwyl die realistiese aannames en veronderstelde geloofskeuse van die Christelike tradisie ewe ernstig opgeneem word. Van Huyssteen rig hom vanuit hierdie basis teen enkele ander

DJ Smit spreek in sy voordrag (wyfel uit of hierdie 'kriteria' voldoende is met dic oog op dic waarheidverwagting van die evangelic (101). Ook verdere kritiek (103).

-. Vgl GC Veldhyusen se voordrag, The authority of the Bible from the perspective of realism (113128 ), as voorbeeld hiervan. Hy bied 'n gerestoreerde Reformatoriese beskouing van Skrifgesag aan vanuit 'n krities-realistiese oogpunt. 
pogings om tot 'n postmoderne benaderingswyse te kom, naamlik die van Nancey Murphy (wat soos Hefner van Lakatos se insigte gebruik maak) en Ronald $F$ Thiemann, wat albei in die laaste instansie terugval op 'n nieu-Wittgensteinse fideïsme en 'language game'-verklaring van godsdienstige uitsprake, en epistemologiese relatiwisme gevolglik nie kan vermy nie. Enige poging om teologie, naas deskriptiewe geloofwaardigheid, 'n geloofwaardige verklaringsfunksie te gee, word so ondergrawe.

Vordering met teologiese verklaring veronderstel dat 'n gegewe verklaring nie alleen die beste beskikbare verklaring is nie, maar dat dit ook teruggaan op geloofstandpunte wat inderdaad as kognitiewe verklarings funksioneer. In teologie is die beter verklaring die een wat lig werp op probleme op die ervaringsvlak én wat konseptuele probleme wat voortvloei uit die interpretasie of verstaan van sulke ervarings, verminder. Die meetpunte of waardes is dan, soos hierbo genoem. Swak teologiese teorieë faal nie alleen in terme van breë, algemene waardes nie, maar ook in hulle eie terme.

Vordering met teologiese verklaring is ook gemik op groter verstaanbaarheid ('intelligibility'). Die waardes waarmee laasgenoemde vordering gemeet word, word gekies in ooreenstemming met die mees basiese kennisoogmerke waarop teologie se rasionaliteit afgestem is. Soos genoem, is teologie se rasionaliteit veronderstel om konsonant met die van wetenskap te wees en is dit op die keper beskou, nie ' $n$ ander soort rasionaliteit as wat in die gewone lewe funksioneer nie. Deur hierdie oogmerke in die oog te hou, verseker teologie dat hy nie afgly na iets soos astrologie nie.

Om saam te vat: Die rasionaliteit van teologie het te doen met die oorkoepelende doel van teologiese teoretisering ('intelligibility') en dit impliseer die verskillende metodes van teologie (as middele tot 'understanding"*), asook dat die hoogste moontlike kenniswaardes in die toepassing van die metodes gehandhaaf word. Rasionaliteit in teologie is nie 'n doel op sigself nie, maar 'n middel tot ' $n$ doel, naamlik verklaring of verduideliking, asook vordering daarmee.

In the end rationality in theology therefore consists of accepting those models of research traditions that are the most effective problem solvers. This form of epistemological adequacy should, however, always be supported by a well-defined experiential adequacy: this can be achieved by showing that because theology is an intellectual

Dit wil voorkom of hier in die rigting van Verstehen geding word, wat dus iets breêr as intellektuele verstaan is. 
activity on the part of a community of inquirers, there can be no way of prescribing a rationality for that activity without also looking at its actual practice (89).

Terwyl dit toegegee moet word dat Van Huyssteen hom in die referaat toespits op rasionaliteit en intellektuele verstaan, is dit nie goed duidelik wat die verband daarmee met meerdimensionele verstaan (Verstehen) is nie.

Van Huyssteen se referaat word gevolg deur die van DJ Smit: Theology as a critical account of personal faith? (91-112). Die geheel van hierdie voordrag is 'n kritiese bespreking van Van Huyssteen se boek, Teologie as kritiese geloofsveruntwoording. Dit is duidelik dat Smit die betrokke boek baie goed onder die knie het en dat hy vrae aan Van Huyssteen vra wat tot op die been kerf. Agterna gesien is dit jammer dat hierdie voordrag in een van die parallelle sessies van die kongres gehou is en nie soos Van Huyssteen s'n tydens die hoofsitting nie. Dieselfde geld vir die voordrag van PJ Naudé.

Smit se standpunt is dat Van Huyssteen 'n onreg aan beide fundamentele teologie en Sistematiese Teologie doen met sy aandrang om dit wat hy doen, sistematiese teologie te noem* Deur die tyd en aandag van Sistematiese Teologie op te eis vir vrae wat eintlik voorvrae is, ontstaan die gevaar dat die vak se eintlike taak en onderwerp verdring word.

Hy is verder van mening dat Van Huyssteen teoloë onnodig kras beoordeel as onkrities en argeloos oor die fundamentele implikasies van hulle werk. Toegegee dat so 'n kritiek van tyd tot tyd nodig mag wees, maar die werk kan nie kort-kort onderbreek word om voorvrae opnuut in hersiening te neem nie.

Met sy tweede vraag/stelling, sny Smit nog dieper. Die teologie moet hom in ten minste drie wêrelde verantwoord, te wete kerk, akademie en samelewing. Van Huyssteen oorbeklemtoon een, te wete akademie, en ignoreer prakties die ander. Dit toevallig juis in 'n tyd wanneer al meer gevra word of teologiese opleiding aan universiteite hoort en daar veral uit die Derde Wêreld ernstige bedenkinge geopper word oor die nou verhouding van teologie met Westerse wetenskap. Prinsipieel kan ook gevra word of die akademie ooit die belangrikste locus of konteks van Christelike teologie kan wees, want dit gaan vir die teologie om die bestaansvrac voordat dit om die verstaansvrae gaan.

Uit die konteks en adres van Van Huyssteen se sistematiese teologie vloei die volgende:

- PJ Naudé suggereer in sy voordrag ook dat Van Huyssteen met fundamentele teologie besig is 
- Die probleembewussyn waarmee hy werk, het te doen met intellektuele probleme, met verstaan, verduideliking en sin in hierdie sin.

- Die verandering wat teologie moet help bewerkstellig, is konseptuele verandering.

- Die sosiale dimensie is uitgesluit as hy sy kriteria vir rasionele geloofwaardigheid formuleer.

- Die hoogste lojaliteit wat die teoloog kan he, is 'n lojaliteit teenoor die wetenskap en metodologiese integriteit.

- Teologie word 'n hoogs individualistiese aangeleentheid. Die kollektiewe subjek (kerk, geloofsgemeenskap, tradisie) vervaag. In die plek daarvan kom die

intimate, esoteric religious experience of the believing theologian as the final source of theology. Theology becomes the critical account of personal faith by an academic theologian (103).

- Dit lei daartoe dat die metodologie van teologie sy hermeneutiese swaartepunt moet vervang met 'n krities-realistiese eksplikasie van die Christelike geloofsaanspraak. Smit maak trouens die stelling dat Van Huyssteen die hermeneutiese geaardheid van Sistematiese Teologie, metodologies gesproke, onderwaardeer. Dit is volgens hom nog 'n bewys dat Van Huyssteen eintlik met fundamentele teologie besig is en nie met Sistematiese Teologie nie.

Die derde vraag/stelling vloei uit die tweede voort. Dit is dat Van Huyssteen nie werklik erns maak met die konteks van teologie nie. Hy gee die betekenis van die verskillende kontekste toe, maar verdiskonteer slegs die akademiese. Die impak van die kennissosiologie, ideologiekritiek en godsdienskritiek, asook die diepgaande implikasies van insigte waartoe in hierdie kritieke gekom is, gaan by hom verby. Smit suggereer selfs dat Van Huyssteen se ontwerp hom tot ideologisering leen.

'n Groot deel van hierdie besware verval wanneer Van Huyssteen se bydrae gesien word as pre-teologies, as 'n oefening in fundamentele teologie, want dan 
word dit minder pretensieus - allermins iets waarvan elke sistematiese teoloog kennis moet neem.

Die voordrag van $P J$ Naudé, The limitations of problem-solving as criterion for paradigms in theology (142-151), sluit nou by die voordrag van DJ Smit aan.

Op voetspoor van Kuhn dui Van Huyssteen werklikheidsbetrokkenheid, probleemoplossing en die progressiewe aard van teologiese uitsprake as kriteria vir die rasionaliteit in sistematiese teologie aan. Dieselfde kriteria dien om die sukses van verskillende paradigmas in verklaring en probleemoplossing te meet. Soos uit die titel van sy voordrag afgelei kan word, het Naudé bepaalde bedenkinge oor 'probleemoplossing' as kriterium.

- Hy dui 'n leemte in die algemene debat (na aanleiding van Van Huyssteen se boek) daarin aan dat dit geen bewussyn van eie kultuur-en tradisierelatiwiteit vertoon nie. Vir 'n nie-Westerse teoloog sal dit niks minder as ' $n$ 'Gestalt'-oorskakeling kos om deel van die debat te word nie. Die blote afwesigheid van so 'n bewussyn by deelnemers aan die debat kan op 'n vorm van wetenskaplike paternalisme dui. Verskeie voorbeelde word uit Derde-Wêreld-teologieë aangehaal om aan te toon dat daar totaal ander verwagtinge van teologie leef, allermins die van kognitiewe en intellektuele groei.

- Die manier waarop Van Huyssteen die beginsel van probleemoplossing aanwend, en die Skrif en die huidige wetenskaplike denke rondom die Skrif as basiskriterium daarbinne aandui, hou die gevaar in van sirkeldenke. Die Skrif ontvang so die rol van outonome norm, terwyl die Skrif ook in die metodologiese twis ingesleep word. Die Skrif kan nie twee rolle gelyktydig vervul nie. In 'n fundamenteel-teologiese debat moet die relatiewe posisie van die Skrif onder oë gesien word.

- Beide Kuhn en Van Huyssteen neig tot 'n onduidelike hantering van die begrippe 'teorie' en 'paradigma'. Naudé beskryf 'n paradigma as 'n veld van teorie ë wat histories of konsepsueel met mekaar saamhang. 'n 'Paradigmaverskuiwing' dui, volgens hom, ' $n$ fundamentele verandering in ' $n$ navorsingstradisie aan, terwyl Kuhn selfs verstellings in 'n teorie met dié beskrywing aandui. Van Huyssteen vaar nie veel beter nie (147).

- Drie argumente word oor die verhouding tussen probleemoplossing en teologiese paradigmas aangebied: 
- 'Paradigma-verskuiwing/rewolusie' is 'n saak wat beter deurgedink moet word. Enige verandering in teologie gaan gepaard met geloofsoortuigings en interesses wat diepgewortel is. 'n Sekere kontinuiteit met die oue kan dus aangedui word. Dan is dit verder so dat sekere veranderings beter in terme van teoretiese ewolusie as - rewolusie verklaar kan word (afhangende natuurlik van die posisie van die beoordelaar). In teologie is dit ook normaal dat verskeie paradigmas wat in kompetisie met mekaar verkeer, naas mekaar (en dikwels kruisbestuiwend interaktief) bestaan. Dit is duidelik dat probleemoplossing in die lig van sulke omstandighede 'n meer ingewikkelde saak word as wat Kuhn voorsien.

- Die probleme wat opgelos moet word, lê nie almal op dieselfde vlak nie en is nie almal ewe belangrik nie. Küng se standpunt is dat slegs oplossings op makrovlak 'n paradigmaverskuiwing tot gevolg kan hè (148). Probleme wat op mikro- en mesovlak opbou, kan natuurlik probleme op makrovlak tot gevolg hê. Dan kan probleemhantering op mikro- of mesovlak paradigmatiese implikasies hê. Daar is egter baie probleme op genoemde twee vlakke en hulle oplossings wat nie sulke implikasies het nie.

- Probleemoplossing is iets wat op baie meer vlakke as die rasionele of intellektuele kan plaasvind of as sodanig aanvaar moet kan word. 'n Oplossing kan allerweë in akademiese kringe aanvaar en op geloofs- of kerklike vlak verwerp word omdat dit te eendimensioneel is. Naudé meen dat paradigmaverskuiwings in die teologie, vanweë die vervlegtheid van die teologie met die geloof en godsdiens en allerlei groeps- en kerklike interesses, hoogs ingewikkelde verskynsels is wat met veel meer as rasionele probleemoplossing te doen het. Hy wys hier op 'n leemte in Van Huyssteen se model deurdat die kognitiewe, begripsmatige, rasionele dimensie daarin ten koste van die affektiewe-mistieke en eksistensiële dimensies oorbeklemtoon word.

Myns insiens opper Naudé hier 'n probleem wat teruggaan na die basis van Van Huyssteen se benadering. Hy se:

Those metaforic and interpreted expressions around which the language of the Christian religion cluster, can in this sense be said to have justified themselves as meaningful and referential to vast 
numbers of people throughout the centuries and across cultures (83). Die verklaringsgeldigheid van genoemde uitsprake knoop terug na die werklikheid van werklike mense en hulle werklikheidservaring. Teen die einde van sy voordrag sê hy:

This form of epistemological adequacy should, however, always be supported by a well-defined experiential adequacy: this can be achieved by showing that because theology is an intellectual activity on the part of a community of inquirers, there can be no way of prescribing a rationality for that activity without also looking at its actual practice (89).

Ten spyte van laasgenoemde uitspraak kan tog vraagtekens geplaas word oor die wyse waarop ervaring en wat Krüger die kulturele en religieuse kondisionaliteit van ervaring noem, in sy model figureer. 'n Mens kan nie help om die gevoel te kry dat ervaring bloot as 'n lanseerplatform gebruik word nie. Ek wonder selfs of sy benadering dit kán hanteer en of hy nie 'n Gestalt-aanpassing daarvoor nodig sal hê nie.

\section{Hermeneutiese ontwikkelinge en Nuwe-Testamentiese ondersoek}

Alhoewel die hermeneutiese vraagstelling dikwels tydens die kongres geopper is, het dit nie so sentraal gefigureer as wat 'n mens sou kon verwag het nie. Uiteraard het dit sterk by die Nuwe-Testamentici na vore gekom.

WS Vorster sluit in sy voordrag, Towards a post-critical paradigm: progress in New Testament scholarship? (31-48), aan by 'n stelling van JP Martin dat elke fase in die ontwikkeling van Nuwe-Testamentiese wetenskap gekoppel kan word aan die algemene wetenskapsbeskouing wat op daardie stadium gangbaar was. Die histories-kritiese bestudering van die Nuwe Testament kom op in 'n tyd toe 'n analitiese, meganistiese en rasionalistiese wêreld- en wetenskapsbeskouing gangbaar was. Waar daar nou allerlei verskuiwings in wêreld- en wetenskapsbeskouing plaasgevind het of steeds aan die gang is, is dit voor die hand liggend dat Nuwe-Testamentiese navorsing geraak sal word.

Hierdie verskynsel kan ook teruggevoer word na die verband wat Thomas

- Dit is 'n verwerking van 'n artikel wat in 1987 in hierdie tydskrif verskyn het (HTS 43/3). 
Kuhn plaas tussen wetenskap enersyds en wêreldbeeld en werklikheidspersepsie andersyds.

Vorster wend Kuhn se kategorieë van paradigma, paradigma-omwenteling, pre-paradigmatiese fase en normale wetenskap aan om te verduidelik wat in die Nuwe-Testament wetenskap gebeur het. In terme hiervan kan die histories-kritiese benadering beskou word as 'n paradigma in Nuwe-Testamentiese ondersoek.

Hy gee 'n nuttige en gebalanseerde oorsig en bespreking van metodevraagstukke wat in die ontwikkeling van die Nuwe-Testamentiese wetenskap na vore gekom het. Hy toon aan hoe daar van 'n tydperk toe 'n simplistiese histories-kritiese benadering van geskiedenis, literatuur, teks, betekenis en wetenskaplikheid die Nuwe-Testamentiese wetenskap gedomineer het, wegbeweeg is na 'n hedendaagse pluraliteit van beskouings van dieselfde sake. Die blote vraag wat ' $n$ teks is, het nou 'n ingewikkelde vraagstelling geword met ' $n$ taamlike spektrum van dimensies. Die eerste verskuiwings weg van ' $n$ uitsluitlik historiese benadering het gekom toe begin is om die teks strukturalisties te benader. Hierna volg die sogenaamde 'Nuwe Kritiek' en hedendaagse teks-linguïstiese teorieë, terwyl die ontstaan van die teks met die perspektief van intertekstualiteit benader word.

Die leser word ook by die teks betrek. Die teks is nie meer 'n objektiewe gegewenheid met 'n vaste bepaaldheid nie. Die mees rewolusionêre benadering is egter die van dekonstruksie:

Texts are no longer regarded as objects. Texts are networks of traces of other texts without centres or margins continually refering to other texts. Meaning seems never to be present in a text. Texts do not have meaning because of their structure, but because of their relationship with other texts in a network of intertextuality (38).

Hierby kom dan ook nog nuwe perspektiewe op die taal en kommunikasie van die Nuwe Testament. Semantiek, linguistiek, sosio-linguïstiek, narratologie, retoriese analise, die verskynsel van veeltaligheid en dies meer is alles sake of oorwegings wat die prentjie baie ingewikkeld maak.

Vorster toon ook aan dat historiese verstaan ewe ingewikkeld geword het, met die sosiale dimensie as ' $n$ vername komponent daarvan by vele moderne Nuwe. Testamentici.

Hy is van mening dat die eertydse toestand van 'normale wetenskap' toe die histories-kritiese paradigma algemeen gangbaar was, vandag plek gemaak het vir 'n 'pre-paradigmatiese' situasie wat gekenmerk word deur paradigmatiese pluraliteit. Alle aanduidings is dat daar ' $n$ verskuiwing is in die rigting van 'n holistiese 
paradigma.

Vorster erken teen die einde van sy voordrag die sosiale karakter van wetenskap, wetenskapskringe en daarmee, in soveel woorde, die verskynsel van sosiale (moontlik ook sosiaal-ideologiese?) aanvaarbaarheid al dan nie van bepaalde benaderings in bepaalde kringe. Hy gee ook erkenning aan die bydrae wat nuwe bloed in die moderne Nuwe-Testamentiese wetenskap gemaak het. Dit bestaan uit navorsers wat die vak uit onkonvensionele hoeke en met taamlike ontradisionele vraagstellinge benader en vars gesigspunte aan die vak introduseer.

Dit is dalk nie onbillik om af te lei (PJvdM) dat die huidige 'pre-paradigmatiese' situasie dus nie alleen die resultaat van metodologiese pluraliteit is nie, maar ook van die verbreding van sosiale horisonne en groter verdraagsaamheid om vir 'n diversiteit van wetenskaps-en geleerdheidskringe, asook kontekste, voorsiening te maak. As met dieselfde breë visie en verdraagsaamheid na die verlede van Nuwe-Testamentiese studie gekyk word, kan die vorige situasie dalk minder lyk na een van 'normale wetenskap'.

Een van die gedagtes waarmee Vorster afsluit, kry hy by die feministiese teoloog, Elisabeth Schüssler Fiorenza. Dit is dat die betekenis en relevansie van die Nuwe Testament in die toekoms eerder dalk in die rigting van prototipiese waarheid as in die van argetipiese waarheid gevind sal word. Die teologiese implikasies hiervan is diepgaande.

$A G$ van Aarde dui sy voordrag, Historical criticism and holism: heading toward a new paradigm? (49-64), aan as 'n respons op die voordrag van Vorster.

Hy erken dat die pluraliteit van eksegetiese metodes en benaderings een van grootste uitdagings is waarvoor Nuwe-Testamentiese wetenskap te staan gekom het. Om die menigte van metodes in 'n geïntegreerde matriks in te pas of 'n sintese daarvan te maak, noem hy 'n aanvegbare moontlikheid onder andere omdat die uiteenlopendheid van metodebenaderings volg uit die uiteenlopende persepsies wat oor die Bybel as kennisbron bestaan.

Nog minder is metodologiese relatiwisme die antwoord. Relatiwisme maak objektiwiteit as metodologiese norm irrelevant en beteken uiteindelik 'n gelykskakeling van beide goed en sleg. Dit misken ook die betekenis van 'n plurale werklikheid.

Vorster betoog dat die toenemende toepassing van die holistiese beginsel op 'n naderende paradigmaverskuiwing dui. Dit is presies die omgekeerde van die analitiese benadering. Waar die analitikus altyd kleiner neig, omdat die waarheid in die kleinste geheel lè, neig die holistikus al groter, want die waarheid lê in die grootste geheel. (PJvdM: Die grootste geheel is dan die organisme en die dele 
daarvan kan hoogstens organe wees. Slegs die organisme kan samehangende betekenis hê. Organe dra deel-betekenisse. Dit baat nie om 'n klomp deel-betekenisse by mekaar te tel in die verwagting dat so by die samehangende betekenis uitgekom sal word nie. Daar moet juis vanaf die organisme na die orgaan beweeg word.).

Van Aarde staan krities teenoor die gedagte dat die toekoms van NuweTestamentiese wetenskap in holisme lê, omdat dit volgens hom onafwendbare relatiwistiese en panteīstiese implikasies inhou. Hy het ook ernstige bedenkinge oor aansprake dat so 'n paradigma-verskuiwing in die geesteswetenskappe en in die Bybelvakke aan die gang is.

Wat ander as 'n holistiese neiging sien, sien hy as 'n toenemende bewussyn van 'n plurale en ingewikkelde wêreld en werklikheid. Die algemene metodologiese en paradigmatiese pluraliteit van vandag vloei ook hieruit voort.

Van Aarde meen dat objektiwiteit steeds as 'n norm of ten minste as 'n ideaal in die wetenskap geld (en dat die digotomie van subjek-objek ook nog van toepassing is). In Bybelse eksegese word allerweë aanvaar dat die teks sekere beperkinge op die eksegeet plaas. (Nuwe ontwikkelinge soos die sosio-historiese en 'dekonstruktiewe' benaderings dui ook allermins op die opkoms van spekulasie en losbandigheid in Nuwe-Testamentiese wetenskap, want hulle het hulle eie kontrolesisteme).

Daar is dus steeds 'n historiese-kritiek van toepassing in die Nuwe-Testamentiese wetenskap, sy dit 'n post-kritiese een. Hierdie moderne historiese kritiek geskied met bewussyn van eie relatiwiteit en voorlopigheid ook relatiwiteit en voorlopigheid van die onderhawige metodologiese stelsel".

Van Aarde glo dat 'kritiese realisme' dit moontlik maak om verdraagsaam teenoor pluraliteit te wees, sonder om relatiwisties te wees. Kritiese realisme erken die voorlopigheid van teorieë en wetenskaplike kennis pertinent. 'n Kritiesrealistiese anhanger van die histories-kritiese benadering is iemand wat stellig is sonder om positiwisties of dogmaties te wees.

Hy meen dat die holistiese beginsel nuttig ingespan kan word, maar hy wil nie graag dat daar na 'n holistiese paradigma, veral soos Capra dit sien, oorgeskakel moet word nie. Behalwe dat 'holisme' vir hom na relatiwisme lei, is dit ook niks anders as panteïsme nie. Panteïsme wis grense en identiteite uit. Immanensie en transendensie word dieselfde. Teologie, psigologie, sosiologie, antropologie, ideologie word uitwisselbaar. 'n Paradigmaverskuiwing in die rigting van holisme

- 'Relatiwiteit' moet nie met relatiwisme verwar word nie. 
kom vir die Nuwe-Testamentiese wetenskap nie neer op vooruitgang nie, maar op selfmoord.

Hy meen in elk geval dat die 'gehele' (= organismes) waarna die holistiese benadering van Capra verwys, slegs in sy teorie bestaan. JC Smuts het dit nie so gesien nie en baie ander metodoloë sien holisme ook nie 'organismies' nie.

As laaste woord oor hierdie voordrag kan gevra word of Van Aarde dit nie teen 'n bepaalde siening van holisme het, eerder as dat hy enige vorm van holisme aanval nie.

Laastens kyk ons in hierdie groep na die voordrag van $B$ Lategan, Why so few converts to new paradigms in theology? (65-78).

Hy toon aan dat daar reeds so vroeg as Schweitzer ingesien is dat groot metodologiese verskuiwings in Nuwe-Testamentiese ondersoek met verskuiwings in filosofie en algemene kennisleer saamhang. Schweitzer het die verskynsel van metodologiese paradigmas raakgesien, ofskoon hy natuurlik nie die term paradigma gebruik het nie.

Lategan stem met Van Aarde saam dat, hoewel daar vir die afgelope paar dekades reeds sprake is van groot metodologiese verskuiwings in die Nuwe-Testamentiese wetenskap, tradisionele werkwyses ongestoord voortgaan. Die historiese kritiek staan nog stewig, sy dit in aangepaste vorm.

Verskeie redes word ondersoek vir die onwilligheid om gevestigde metodes met nuwes te vervang. Die persoonlike style van diegene wat die nuwe benaderings propageer en die verskynsel dat sommige tradisionele metodes in skole gevestig is, wil daarop dui dat sosiale faktore nie buite rekening gelaat kan word nie.

'n Verdere faktor is dat tradisionele eksegetiese metodes die metodologiese basis vorm van 'n groot deel van die verdere teologiese corpus wat oor jare heen opgebou is. Verskuiwings op eksegeties-metodologiese vlak het 'n golfeffek dwarsdeur die teologie. Eksegete staan nie los van die res van die teologie nie. Indien vermoed word dat ' $n$ nuwe benadering nog in die eksperimentele stadium verkeer of nie verder as dit gaan kom nie, sal dit nie die oue verdring nie. Dit sal ook nie gebeur as sulke benaderings slegs deeloplossings bied nie.

Lategan se indruk is dat daar tans 'n soort storm-en-drang-situasie geld, maar dat die fundamentele probleme onopgelos bly.

Voordat 'n paradigmaverskuiwing kan plaasvind, is dit nodig dat 'n duidelike patroon vorm sal aanneem waarvolgens geïntegreerde probleemidentifikasie en oplossing in terme van die nuwe metodologiese beginsels voorsien kan word. Hy stel voor dat dit gesoek moet word aan die hand van die vraag, wat is die 'objek' wat ons probeer interpreteer, eerder as om te vra: Wat is die beste metode?

Dit bring ons terug by die teks en by die wese, aard en kenmerke daarvan. 
Die drie vernaamste aspekte van die teks is die historiese, strukturele en teologiese (of kontekstuele) aspekte daarvan. Die interpretatiewe benadering van die historiese kritiek, soos oor jare aangepas en in die moderne tyd uitgebrei om die strukturele en teologiese aspekte van die teks ook te kan aanspreek, blyk die beste te wees wat ons tans het, as ons na 'n geïntegreerde benadering vra.

Lategan suggereer dat daar in die toekoms meer indringend gekyk moet word na die dialektiek tussen die statiese en dinamiese dimensies van die teks. Hiervoor kyk hy kortliks na Ricoeur en Rousseau (vgl ook die voordrag van Rousseau), en maak hy ook eie opmerkings. Hy sluit af met die volgende belangrike gevolgtrekking:

... paradigms are problem-solving devices and not escape routes to avoid difficult issues. It might well be that time spent in struggling with existing problems may bring with it the bonus of a more convincing paradigm.'

\section{'Foundationalism'}

Hierdie term, waarvoor daar helaas geen Afrikaanse ekwivalent bestaan nie, is 'n neologisme uit die Angelsaksiese wêreld (Gerard Radnitzky). Dit dui 'n rigting aan waarvan die wortels volgens $J$ Mouton en $J C$ Pauw, Foundationalism and fundamentalism: a critique (176-187), in der waarheid na die sestiende-sewentiende eeu teruggaan. Hulle som die kernoortuiging daarvan soos volg op:

Die elemente van kennis (wat in hierdie geval proposisies genoem kan word) val in twee klasse uiteen, te wete basiese proposisies en nie-basiese proposisies. Basiese proposisies is direk geldig, as't ware selfevident, en vorm die grondslag en beroep van nie-basiese proposisies. Dit maak ook die fondament van alle kennis uit.

Dié benaderingswyse val uiteen in 'n rasionalisme (Descartes) en 'n empirisme (Bacon en Locke), maar dié twee rigtings stem uiteindelik saam dat wetenskap slegs moontlik is as dit op ontwyfelbare sekerhede (empirie/selfevidente idees) gebou is. Ook Kant kan in 'n sekere sin 'n foundationalis genoem word.

Mouton en Pauw kritiseer foundationalisme op twee punte. Eerstens het hulle dit teen 'n naïewe opvatting van sekerheid wat die opvatting van 'basiese proposisies' onderbou. Tweedens het hulle dit teen die naïewe wyse waarop foundationaliste meen nie-basiese proposisies van basiese proposisies afgelei word 
en wat nie rekening hou met die ingewikkelde en geweefde werklikheid van teorieë en wetenskap nie.

Dit is egter van betekenis dat hulle dit nie teen sekerhede as sodanig het nie.

Of course we are certain of many things, depending on our situation. It is part and parcel of being sane. The anti-foundationalist theologian should have no problem with certainty regarding elements of his faith. What he/she refuses to do, however, is to situate these certainties at the base of his/her theology, and attempting to infer the rest of the edifice of theological knowledge from them (185-186).

Die prentjie van foundationalisme wat uit die voordrag van EJ Echeverria, Foundationalism, evidentialism and the rationality of religious belief (187-205), na vore kom, lyk nogtans meer verfynd en oorwoë as wat 'n mens na aanleiding van die vorige twee here se voordrag sou verwag.

Hy gee eers 'n algemene beskrywing van klassieke foundationalisme, met evidensialisme as uitloper, en nie-klassieke foundationalisme. Vervolgens bespreek hy Stephen $T$ Davis as 'n eksponent van die klassieke foundationalisme en Alvin Platinga as eksponent van die nie-klassieke foundationalisme. Die vraagstelling waarom dit wentel, het te doen met die rasionele oortuiging en regverdiging van persoonlike geloof.

Vanweë die argumentatiewe styl van die voordrag, kan moeilik 'n samevatting daarvan gemaak word. Derhalwe word met 'n paar opmerkings volstaan wat ek hoop ' $n$ billike weergawe is.

Davis se denke is 'n soort evidensialisme - dit aanvaar slegs standpunte of proposisies wat op direkte waarneming gebaseer is of wat selfevidente of noodwendige waarhede verteenwoordig. Hy sien die probleem van oneindige regressie in begronding onder oë, maar wys daarop dat die skeptikus (wat per definisie dan ook foundationalisties sal dink), voor 'n derglike probleem te staan kom as hy gegronde twyfel wil opper. Hy gee egter toe dat geloof nie geregverdig word deur skeptici af te skrik nie. Daarom is hy bereid om ander beweegredes in die plek van gronde te aanvaar. Dit vind hy in veronderstellings wat uit die praktiese lewe voortspruit en in geloof ('faith') - dinge wat vir hom op dieselfde vlak as 'common sense' lê. As gevolg van hierdie toegewing sien hy die rasionele regverdiging van geloof hoogstens in 'n 'weak sense of rationality', wat die waarde van Davis se oefening in die wetenskaplike kader onder 'n vraagteken stel.

Echeverria identifiseer die sleutelgebrek in Davis se skema daarin dat hy te maklik aanvaar dat oneindige regressie nie vermy kan word nie. Hy bied dan 'n 


\section{Paradigmas en progressic}

moontlike oplossing aan: daar kan in die lewe van die gelowige sekere geloofsoortuigings (en -ervarings) wees wat die status van prima facie-evidensie het en wat nie nodig het om begronding buite hulleself te soek nie.

Platinga verwerp evidensialisme. Hy sê dat 'common sense'-oortuigings en geloofsoortuigings redelik en basies kan wees sonder om verdere bewyse of gronde te behoef. As dit nie mag nie, stort 'n groot deel van wat allerweë as redelikheid aanvaar word in elk geval in duie.

Geloof is nie per se irrasioneel nie. Geloofs- en/of werklikheidservarings kan as prima facie-getuienis vir 'n bepaalde geloofsoortuiging aanvaar word - so 'n geloofsoortuiging kan selfs wees dat God en die bestaan van God die grond van alle waarheid en werklikheid is. Platinga stel dat daar in die normale lewe baie sulke grondaannames funksioneer wat op die keper beskou niks meer as oortuigings is nie en wat op prima facie-gesag gebaseer is nie. Hy noem persepsuele oortuigings onder andere as 'n voorbeeld.

Soos ander aannames is geloofsmatige grondaannames onderworpe aan veranderende omstandighede, ander ervarings en insigte, kritiese denke en dies meer. Die voordeel van Platinga se skema is dat dit die redelikheid van geloofsoortuigings nie op 'n ander vlak as gewone redelikheid plaas nie.

Dit is duidelik waarom Echeverria Platinga 'n baie onkonvensionele foundationalis noem. As ek Platinga (soos aangebied deur Echeverria) reg verstaan, kan ek nie sien waarom sy skema vir persoonlike geloof kan doen wat Van Huyssteen se swak-kritiese-realistiese skema vir wetenskaplike teologie wil doen nie. Daar bestaan selfs die moontlikheid om hulle met mekaar te skakel.

\section{'n Hermeneuties-fenomenologiese benadering}

Die voordrag van JS Krüger, Conditionality, religious experience and conceptualisation (209-222), verteenwoordig hierdie benadering. Hy wil aan die hand van bepaalde meta-teologiese oorwegings kom tot ' $n$ meer universeel bewuste en gerigte teologie.

Die eerste deel van sy voordrag bestaan uit 'n voorraadopname van die verskillende sake en dimensies wat ter sprake is wanneer die begrip teologie ter sprake is. Hy noem die volgende:

* Die faktor wat teologie saambind, is dat dit uiteindelik oor God handel.

- Teologie is altyd godsdiensspesifiek.

- Die historiese dimensie. Teologiese uitsprake moet altyd een of ander verwysing of verband met die oorspronge en bronne, en met die tradisie hê. 
* Die konsepsuele dimensie. Teologie is 'n soort metafisika. Waar begripsvorming en -formulering rudimentêr in mite en onderliggend in mistiek funksioneer, is dit eksplisiet in teologie. Alle teologie is daarom ook sistematies en teoreties, wat beteken dat kriteria wat op houdbaarheid as sodanig betrekking het, ook onvermydelik in die teologie ter sprake sal kom.

* Die sosiale dimensie. Die teoloog funksioneer altyd in een of ander sosiale konteks, of hy hom nou in of op die rand van die kring wil plaas. Sosiale interaktiewe dinamiek is daarom 'n faktor wat onder oê gesien moet word.

- Die emosioneel-konatiewe dimensie. Dit is ook altyd deel van teologie, of dit goed sigbaar is of nie. Verskeie soorte gevoelens en verbintenisse, wat in die laaste instansie met God verband hou, laat hulleself geld.

In die tweede deel van sy voordrag skets hy meer algemene faktore wat dui op 'n dinamiese interafhanklike werklikheid/wèreld waarin teologie onvermydelik funksioneer en waarvan 'n metateologies-bewuste teologie kennis moet neem.

\section{Godsdiens}

Enige teologie moet ' $n$ teorie van godsdiens hè. Krüger bied die buitelyne van so 'n ontwerp aan. Godsdiens word onder andere voorgestel as gekondisioneerde ervaring van die kondisionaliteit van die werklikheid én 'n poging om bo dit uit te kom.

\section{Godsdienstige samehange}

Alle historiese godsdienste skakel in groter godsdienstige samehange. Benewens die groot familiesamehange is daar ook ander samehange. Samehang beteken in hierdie verband ook interaksie in verskillende betekenisse van die woord.

\section{Kontekstuele interaksie}

Godsdiens verkeer altyd in een of ander simbiotiese verhouding met sy konteks, hoe hierdie konteks ook al gesien word. Dieselfde geld vir teologie - iets wat teologie net tot sy eie skade kan miskyk.

\section{Intergodsdienstige dinamika}

Die interaksie tussen godsdienste en godsdienstige idees waarna vroeër verwys is, neem vandag 'n nuwe vorm aan as gevolg van die plurale situasie wat ontstaan het. 
Dit het by teoloë die behoefte laat ontstaan om 'n paradigma te vind aan die hand waarvan die verhouding tussen godsdienste bedink kan word. Krüger noem verskeie sulke ontwerpe, soos dat alle godsdiens basies identies is, dat godsdienste op geen manier met mekaar vergelyk kan word nie (bv Kraemer), die eksklusiwistiese standpunt (ook Kraemer), die inklusiwistiese standpunt (bv Rahner) en konvergensie (wat hy self voorstaan).

Teologie kan op geen manier ontkom aan 'n theologia religionis religionumque nie. Dit moet egter met 'n sensitiewe historiese, fenomenologiese en hermeneutiese bewussyn (my terme) geskied.

In die laaste deel van sy voordrag skets hy 'n ontwerp van Christelike teologie wat erkenning verleen aan die werklikheid van godsdiens en godsdienstige werklikhede van die geskiedenis en vandag.

Eerstens stel hy dat teologie dit altyd weer vir homself moet uitmaak waarin die Christelike kontinuum geleë is. Dit is natuurlik ' $n$ taak met geweldige metodologiese voetangels, maar so 'n oefening sal in elk geval 'n historiese en 'n hermeneutiese dimensie hê, en eietydse insigte sal ook hulle rol speel. Op grond van sy standpunt van konvergensie is hy self is ' $n$ voorstander daarvan dat daar vir die nuwe verstaan van die Christelike nie net by die streng histories Christelike gebly word nie.

The other religions would not be voices heard form afar outside Christian theology; they would resound within Christian theology (219).

Tweedens veronderstel teologie die voortdurende heroorweging van opvattings konsepsuele hersiening. Wanneer teologie bokant kondisionering wil uitkom, volg dit vanself dat hy 'n hele spektrum van alternatiewe segginge en konsepte in aanmerking moet neem. As dit toelaatbaar is om voorstellings, uitdrukkingswyses, begrippe uit ander vakgebiede in hierdie spektrum toe te laat, is dit seker nie verkeerd om dieselfde met voorstellings en begrippeskat uit ander godsdienste te doen nie.

Die toepassing van hierdie twee werksbeginsels sal teologie in staat stel om die pad na 'n nuwe universele toepaslikheid vir die Christelike visie aan te dui.

Hy pleit dus vir 'n universele visie in die teologie en 'n houding van universele solidariteit en verantwoordelikheid, wat voortvloei uit die oortuiging van die universele aanspraak en toepaslikheid van dit waarmee die teologie in die laaste instansie besig is.

'n Mens hoef nie met alles wat Krüger sê, saąm te stem om agter te kom dal 
belangrike sake geopper is nie. Sy fenomenologies-hermeneutiese benadering stel hom in staat om sake raak te sien en te bedink wat andersins dalk nie moontlik sou wees nie. Enige poging om tot 'n meta-teologie of selfs 'n fundamentele teologie te kom, moet hiervan kennis neem.

\section{SLOT}

Hoewel die tema van die kongres rondom 'paradigmas en progressie' gewentel het, het 'n baie groter terrein in die gesigveld van die kongresgangers verskyn. Uit hierdie beperkte oorsig van voordragte blyk dit ook, asook die diversiteit van metodologiese hoeke en benaderings.

'n Vraag wat selde eksplisiet gefigureer het, maar heeltyd implisiet was, is die vraag wat teologie veronderstel is om te wees, in watter veld van interesse dit inpas en wat die roeping en missie daarvan is. As 'n mens terugkyk, wonder jy hoe dit eintlik moontlik was om die onderhawige kongrestema aan te pak sonder dat daar vroeër op soortgelyke wyse oor die voorvraag na die teologie self gehandel is, veral waar daar vandag op al meer uiteenlopende wyses oor teologie gedink word (vgl bv Naudé 144).

Miskien moet die volgende RGN-kongres oor hierdie en ander voorvrae in die teologie handel.

\section{Literatuurverwysings}

HICK, J 1985. Problems of religious pluralism. London: Macmillan.

KUHN, T 1970. The structure of scientific revolutions. Chicago: University of Chicago Press.

VAN HUYSSTEEN, JWV 1986. Teologie as kritiese geloofsverantwoording: Teorievorming in die sistematiese teologie. Pretoria: RGN. 